\title{
Leaders of Slum Dwellers - A study based on slums of Jaipur city
}

\author{
Author: Dr. Ambey Kumar Srivastava \\ Institute of Health Management Research, Jaipur, India
}

\begin{abstract}
Growth of slum is largely viewed as an outcome of the failure of urban planning, rising urban population, industrialisation and urban poverty. But the role of 'slum level leader', who is well knitted in the life of slum dwellers and whose greed and guidance largely govern the process of slum growth is not deeply understood. In the current paper attempt has been made to understand the role of slum level leaders in growth of slum and the life of slum dwellers. The study was conducted in Jaipur city and the data was collected from 257 households of eight slums. These slum level leaders share commensal relationship with slum dwellers. They allow a new inmigrant to get accommodated in slum and help in receiving different facilities. In turn, they get recognition, higher social status, political mileage and monetary benefits from slum dwellers. But this give and take relationship between the community and slum level leaders has done more harm than good to the development of slum. Now the time is to deeply understand the role of slum level leaders in social, economic and political environment of slum and using it judiciously to make life of slum dwellers better.
\end{abstract}

Key words: Growth of slums, Slum dwellers, Leaders, Politics, Slum development

\section{Introduction}

The word "slum" is a catchall for poor housing of every kind as well as a label for the environment (Abrams, 1964). Even after so much of advancements in human life, it has not become possible to get rid of slums. Slum may be with us always (Abrams, 1964) because housing entrepreneurs do not build for the poor, as poor cannot pay the rent determined by the market (Desai \& Pillai, 1970). As the world is going urban at rapid pace, the issue of urban housing is getting as bigger. The land shortage is a major issue for urban housing; hence the slums have become an unavoidable truth, especially in developing countries. Squatters usually capture government land on the periphery of cities and towns in the hope that political allies will support them and permit them to stay (Coit, 1995).

Growth of slum is not a new phenomenon. Several theorists have attempted to understand and explain the processes led to emergence and growth of slums in physical, social and economic dimensions. The theorists have attributed lacunas in structural planning of urban land, failure of urban policies, development factors like industrialisation, economic factors like lack of capacity to pay the cost of housing by the poor in-migrants and social factors like kinship, religion or caste as major causes which either compel the migrants to choose housing in slum or make them confident that their social security will not be threatened here.

But beyond these factors, there is an important human character as well who is well knitted in the life of slum dwellers and whose greed and guidance govern the whole process of slum growth by taking advantage of urban discrepancies, desire of inmigrants to get urbanised and helplessness to return the native village. These characters are "elites" of the slum and are known as 'slum leaders'. Slum community leaders are held in high esteem (Mathur, 1996). May be because, sympathy of those leaders is important for a migrant to become a legal resident of that slum. These leaders play a significant role in emergence, expansion and survival of slums. In the current paper an attempt has been made to understand the role of slum level leaders in slum growth and life of slum dwellers.

\section{Methodology}

The study was carried out in Jaipur city as part of thesis work 'The Urban Poor In Slums of Jaipur City', which was an anthropological study, conducted under department of Anthropology, University of Rajasthan. Jaipur is capital of the state of Rajasthan and worldwide known for its scientific town planning. Jaipur is India's $7^{\text {th }}$ fastest growing city and the $24^{\text {th }}$ fastest growing urban centre in the world (City Mayor Statistics, 2010). Main economic drivers in the city are trading, administration and tourism activities and local handicrafts industries. Along with educated inmigrants the city also offer impressive job opportunities to the inmigrants in informal sector. There are number of factories of handicraft, carpet, precious and semi precious stones, block printing, dyeing, jewellery, glass work and textiles. These industries need cheap and intensive human labour, which is provided by the inmigrants. 
The Jaipur city has 211 slums ${ }^{1}$, which are called as 'kacchi basti' in local parlance. As per census 2001, the slum population was 350,353 , which was $15.07 \%$ of total population $(2,324,319)$ of the city. In the study the data was collected from 257 households, distributed proportionately in 8 slums, namely, Bhojpura, Jawahar Nagar Tila -2, Biharion ka Tila, Fauji Nagar, Kathputli Nagar, Reech Bandar walon ki basti, Jhalana Mahal Kunda and Tamil Colony. The distribution of respondent households in study slums is shared in table 1 . The data was collected through structured household level questionnaire and qualitative discussion with respondents. In the current chapter the only issues which are related to leadership in slums are analysed and shared.

Table-1: Study slums and distribution of the sample households

\begin{tabular}{|l|c|}
\hline Study slums & Number of Sample Households (\%) \\
\hline Bhojpura & 41 \\
& $(15.95)$ \\
\hline Jawahar Nagar Tila-2 & 48 \\
& $(18.68)$ \\
\hline Biharion ka Tila & 37 \\
& $(14.40)$ \\
\hline Fauji Nagar & 14 \\
& $(5.46)$ \\
\hline Kathputli Nagar & 60 \\
& $(23.45)$ \\
\hline Jhalana Mahal Kunda & 10 \\
& $(3.89)$ \\
\hline Tamil basti & 39 \\
& $(15.18)$ \\
\hline Total & 8 \\
& $(3.11)$ \\
\hline
\end{tabular}

Source: Srivastava, A., The Urban Poor in Slums of Jaipur City, Ph.D. Thesis, Department of Anthropology, University of Rajasthan, Jaipur, 2008

\subsection{Leadership in study slums}

\section{Results and Findings}

Table 2 shows that there was more than one leader in slums. In all the study slums, 38 persons were identified as leader of slum dwellers. In all the sample slums the number of leaders/ influential was more than one, except at Tamil basti and Fauji Nagar basti. There were 5 in Kathputli Nagar, 5 in Jhalana Mahal Kunda, 10 each in Jawahar Nagar Tila-2 and Biharion Ka Tila slum, 4 in Bhojpura kacchi basti, 2 in Reech Bandar walon ki basti and one each in Fauji Nagar and Tamil basti. Most of the leaders were the resident of study slum, but four were living outside slum at a different location.

Table 2:Leaders in study slums

\begin{tabular}{|l|c|c|c|}
\hline Study slums & $\begin{array}{c}\text { Resident of study } \\
\text { slum }\end{array}$ & $\begin{array}{c}\text { Not resident of study } \\
\text { slum }\end{array}$ & Total \\
\hline Jhalana Mahal Kunda & 3 & 2 & 5 \\
\hline Tamil basti & 1 & - & 1 \\
\hline Bhojpura kacchi basti & 4 & - & 4 \\
\hline Jawahar Nagar Tila-2 & 9 & 1 & 10 \\
\hline Fauji Nagar & 1 & - & 10 \\
\hline Biharion ka Tila & 8 & 1 & 5 \\
\hline Kathputli Nagar & 5 & - & 2 \\
\hline Reech Bandar walon ki basti & 2 & - & $\mathbf{3 8}$ \\
\hline Total & $\mathbf{3 4}$ & $\mathbf{4}$ & 10 \\
\hline
\end{tabular}

Source: Srivastava, A., The Urban Poor in Slums of Jaipur City, Ph.D. Thesis, Department of Anthropology, University of Rajasthan, Jaipur, 2008

\footnotetext{
${ }^{1}$ Figure of slum is taken from web site of Jaipur Municipal Corporation, on 02.01.2013, http://oswal.selfip.com/jaipurweb/UI/Static/staticpage.aspx?pageid=9
} 
At Kathputli Nagar slum, a doctor was running a private clinic from last few years. People had lot of faith in him because of his profession and due to his concerns for issues of the slum. So they took him as their leader. Jhalana Mahal Kunda slum was developed by the mine owners of Jhalana as mining at Jhalana hills was allowed at that time and number of inmigrants from nearby districts were recruited by the mine owners for mining work. At Jhalana Mahal Kunda slum the leadership was divided among two influential, who were the owner of Mines in that slum. Both these leaders themselves were not the dweller of Jhalana Mahal Kunda slum but become leaders because they were affluent and had employed slum dwellers in mines. At Bhojpura slum, a person of different state was recognized as leader because of his ability to handle issues of people of Bhojpura slum. Bhojpura slum is regularized and has constructed road and drains. Many dwellers of Bhojpura slum, who accepted him as their leader, said that it was all due to his efforts.

In Fauji Nagar, the people gave credit for the emergence of slum to a local influential person, who worked in defence, popular by the name Fauji., to whom they called their leader as well. Respondent slum dwellers opined that nobody could construct house without seeking his permission. Leadership of Tamil basti and Reech Bandar walon ki basti slum was in the hand of a senior female at the time when this study was conducted. Leader of Tamil basti got the credit of arranging water tanker and constructing road in slum. Many a times she had congregated women of Tamil basti to gherao government office, responsible for water supply in the slum. Leader of Reech Bandar Slum had tried hard for the rehabilitation of slum dwellers at new rehab site Paladi Meena, where some of the slums have been rehabilitated by the local administration.

\subsection{Role of slum leaders}

Growth of slums: Qualitative data analysis shows that in growth of slums the role of local leaders and business contractors was pivotal. The emergence of most of the study slums was not possible without assistance of the slum level leaders, who in turn had/ have connection and hidden support of the local leaders affiliated with political parties, as shared by the respondents. The slum level leaders help people in squatting over the vacant land like in slums- Kathputli Nagar, Bhojpura and Biharion Ka Tila, Jhalana Mahal and Fauji Nagar. Sometimes not only for squatting, even for construction also one has to take their permission. Some respondents of Fauji Nagar mentioned that they had given money to squat over the land and to construct house. In Biharion ka Tila too, some respondents shared that, they had paid some amount to the influential persons of other attached slum to squat over the land.

Slum development: The development of slum is a big issue because slums are deprived of basic urban facilities. Slum level leaders strive for those facilities, especially water, electricity, road and drainage. The slum leaders take advantage of these problems. They put forth demands to the leaders of the area like ward Councillor/Corporator (Parshad), Member of Legislative Assembly (MLA) and local urban development authorities.

Create vote bank: In 2001 the slum population of India was estimated to be 75.26 million, constituting $26.31 \%$ of the urban population of the country and as per projection the slum population will cross 100 million by 2015 (Report of the Committee on Slum Statistics/ Census, 2010). These figures reveal huge potential of vote bank, and the reason why slum level leaders are used by local political leaders to sensitize slum dwellers in their favour?

Slum dwellers, too are aware of this fact and they also try to get favour of the political leaders, mainly for slum regularization. This is why they are devotedly involved in political issues that affected their lives, both within the slum areas and in the wider context (Nylund, 2009). The study data in the table 3 too proved the participation of slum dwellers in casting vote in last general elections for Parliament and assembly election of the state. More than half $(57.98 \%)$ of the total respondents had cast their vote in both the elections, followed by $12.06 \%$ and $8.95 \%$ in General election and State assembly election, respectively. $13.23 \%$ were not eligible to cast vote because they did not have their name in the voter list where as $7.78 \%$ did not cast vote in both the last elections. 
Leaders of Slum Dwellers - A study based on slums of Jaipur city

Table-3: Respondents casted vote in last election

\begin{tabular}{|c|c|c|}
\hline S. No. & Election & Number of Respondents (\%) \\
\hline 1. & State assembly election & $\begin{array}{c}23 \\
(8.95) \\
\end{array}$ \\
\hline 2. & General election & $\begin{array}{c}31 \\
(12.06)\end{array}$ \\
\hline 3. & Both the elections & $\begin{array}{c}149 \\
(57.98) \\
\end{array}$ \\
\hline 4. & None of the election & $\begin{array}{c}20 \\
(7.78)\end{array}$ \\
\hline 5. & Not eligible to cast vote (name was not in voter list) & $\begin{array}{c}34 \\
(13.23)\end{array}$ \\
\hline & Total & $\begin{array}{c}257 \\
(100.0)\end{array}$ \\
\hline
\end{tabular}

Source: Srivastava, A., The Urban Poor in Slums of Jaipur City, Ph.D. Thesis, Department of Anthropology, University of Rajasthan, Jaipur, 2008

Shield of slum dwellers: Slums are encroachment or squatting on urban land due to which the fear of displacement always looms over the slum dwellers. Slum level leaders try to protect the slum from displacement by organising slum people to protest any such move by the local administration.

\subsection{Issues helpful in becoming slum leader}

There are several issues which prove helpful in becoming a slum level leader and have been used by them to increase their aura in slum. The different issues have been shared as under:

Caste and religion: In the slum culture the emotions are important factors in determining the slum leadership. Religious, linguistic, caste or regional organisations are often represented in slums. The people are organised neither as workers nor as slum dwellers but as residents of a village/district or as members of a caste (Pendse, 1970). People of the caste which dominates the slum try to choose their own leader. Like in Kathputli Nagar slum leaders belongs to Meghwal, Bhat and Harijan caste. At Biharion ka Tila Muslim households had their own leader because their number was high. Same was the case at Tamil Basti and Reech Bandar walon ki basti.

Social status: Besides caste, religion and population, the financial status, helping attitude, connections with political leaders, political parties and ability to handle slum issues are also the key determinants in establishing one's leadership or influence in the slum. Slum level leaders use their social status in allowing or disallowing a new entrant in slum. They also help in getting job in cities, like in case of Jhalana Mahal Kunda slum, where only those inmigrants were allowed who were doing labour in mines at that time. Later on when mining was legally banned, many mine workers either changed their job or left the slum. Slum level leaders also use their skill and ability in resolving community level disputes.

Development of slum: Slum level leaders used to share sentiments of slum dwellers because they know it is important for them to win trust of the people. Several times the issues like water, sanitation, road, security of tenure, drainage etc. are raised by them during meetings, visits of the political leaders and local authorities. The development of slum may not happen for a long time, but the slum leaders are able to build their own credibility among the community by raising such demands publicly.

Social welfare: Slum dwellers are mainly immigrants who don't have any root in the city. They are the resident of elsewhere who are looking to reap fruits on a strange land. They want identity of honourable citizen to demand for their rights. Several government schemes are available for poor people but they cannot be accessed by slum dwellers because they lack identity proofs like ration card, Below Poverty Line (BPL) card and voter card which are important to get several facilities at household level and also to make a claim as an eligible beneficiary. These are the weaknesses of migrants to approach local leaders because identity proofs cannot be prepared without getting attested by the recognized authority. On the other hand to political leaders, although slum dwellers provide a readymade vote bank but this vote bank is of no use until they have identity proofs to certify themselves as an eligible voter.

It is here, where the slum level leaders portray the face of a social service man. They help slum dwellers in getting and attesting the identity proof documents through ward Councillor/ Corporator (Parshad) or by any other recognised authority. Those who can't afford the cost may have to wait longer. Slum leaders also use their influence in resolving inconsequential problems like arranging water tanker, getting electric connection etc. 
Threat of eviction: Security of tenure is a major issue in slum development, until the slums have not been regularised. A large number of slums are non-regularised. Under the viable options, slums can either be regularised at the existing place or rehabilitated at a new place. Therefore, the threat of destruction of housing structures in the name of slum rehabilitation, expansion of infrastructure like road, water pipeline, flyovers etc. largely looms over the slum dwellers. The slum leaders also take advantage of this fear in the community. They protest any such moves, undoubtedly for their personal gains, but they are the one who fend the slum dwellers from such threats.

\subsection{Benefits of slum level leadership}

In this commensal relationship both slum dwellers and the slum level leaders are benefited. Slum level leaders were not found as a whole time leader but invest sufficient time because they don't want to lose benefits of being a leader of the community. The perceived benefits of being a slum leader can be summarized under as following:-

Rise in social hierarchy: In slums the people of different villages, states, region, religion, caste and occupation live together as a closed group. But this small society is also segmented in rich and poor, upper caste and lower caste, and literate and illiterate like a traditional Indian society. In a slum, becoming a leader of small group improve the social status among slum dwellers. It gives a sense of identity to a rural migrant on urban land.

Source of Income: Many of the acts for which slum dweller feel indebted to slum level leaders are not the charity work because slum leaders charge an affordable amount against such assistances or take a part of the amount as service charge. So it becomes a sort of income source for them. During interviews the people mentioned about paying money to slum leaders for encroaching land, constructing structures, attesting identity proofs etc.

Political mileage: Slum level leaders act as representative of local political leaders and political parties to mobilize support of slum dwellers in their favour. So these leaders try to inhabit more people of their caste and community. Higher population of their caste or community is good to prove their dominance in the slum.

\subsection{Perception of the slum dwellers about slum leaders}

Till discussion it is clear that slum leaders do have significance in slums and life of slum dwellers. But the perception of slum dwellers about these slum level leaders was not uniform. On one hand there were community based leaders in all study slums, on the other hand many people neither had any such leader nor any faith in them. This difference in opinion of the people about slum level leadership was more evident when respondents were asked about the reasons due to which their slum was not developed so far. They opined that development of slums and slum dwellers is neglected because they don't have any charismatic leader, who can unite them on slum issues.

People of one community condemned the slum level leaders of other community. There were complaints about the discrimination and favouritism by these leaders, which promote disharmony among slum dwellers. Those who lacked faith in them opined that slum leaders play with emotions and take advantage of the miseries of slum dwellers. They tried to make money from slum people in the name of charity work, providing help in making BPL card, Ration card, Voter card, enrolling name in the survey list etc.

People said that slum leaders exhibit their influence over slum to get political mileage by aggregating slum dwellers in political rallies. At Bhojpura slum people shared a bad experience of attending a rally of a political party in different city. They said that when the rally was over, nobody was bothered for them. Respondents remarked, "We know that we are used by slum leaders to attend local political rallies, chant slogans, and join protests and processions. Whenever any rally is to be organized or any national level leader arrive in city for campaigning, people from slums are loaded in buses for hooting, clapping and to show gathering. We have only that much importance to them." People were found highly disappointed with leaders of different political parties, who visited their slum during election campaigns but did nothing thereafter.

The interaction of slum dwellers with MLA and Parshad was not very frequent as they occasionally visited the slum. Slum level leaders are the one who always live with them and act as a bridge between slum dwellers and the local political leaders. Slum dwellers have direct interface with the slum level leaders so these leaders have to bear the consequences of failure of the leaders of the political parties in favour of whom they did campaigning. Such actions of the political parties tarnish the image of the slum level leaders. This was one of the reasons that many people did not call anybody as their leader at slum level. They got angered when asked about any leader, to whom they favoured in the slum.

It was also reflected in the data in table 4 , where only $63.42 \%$ respondents knew the name of the leader of their slum. Remaining $36.58 \%$ either did not know the name of the leader of slum or did not accept any body 
as their leader. Many of those respondents, who were able to mention the name of the slum leaders, were unaware about the name of the elected representatives like member of legislative assembly (MLA) and Parshad (Corporator) of their area. When respondents were inquired about the satisfaction level with the work of leaders in their area, only one-fourth respondents were satisfied with their work. More than half $(51.75 \%)$ were dissatisfied with the work of slum level leaders, as shown in table 4 below. Another important conclusion is that out of 94 respondents who did not know the name of slum leader, $30.85 \%$ of them were satisfied with the work of slum level leaders. It shows that people think that slum level leaders are helpful for them, either they recognise their leadership or not.

Table- 4: Satisfaction with work of slum level leaders

\begin{tabular}{|c|c|c|c|c|c|}
\hline \multirow[t]{2}{*}{ S. No. } & \multirow[t]{2}{*}{ Options } & \multicolumn{4}{|c|}{ Satisfaction with the work of slum leaders } \\
\hline & & Satisfy & Partially satisfied & Dissatisfy & Total \\
\hline 1. & $\begin{array}{l}\text { Respondents who know the name of } \\
\text { slum leader }\end{array}$ & $\begin{array}{c}37 \\
(56.06)\end{array}$ & $\begin{array}{c}41 \\
(70.68)\end{array}$ & $\begin{array}{c}85 \\
(63.90)\end{array}$ & $\begin{array}{c}163 \\
(63.42)\end{array}$ \\
\hline 2. & $\begin{array}{l}\text { Respondents who did not know the } \\
\text { name of slum leader }\end{array}$ & $\begin{array}{c}29 \\
(43.94)\end{array}$ & $\begin{array}{c}17 \\
(29.32)\end{array}$ & $\begin{array}{c}48 \\
(36.10)\end{array}$ & $\begin{array}{c}94 \\
(36.58\end{array}$ \\
\hline & Total & $\begin{array}{c}66 \\
(100.0)\end{array}$ & $\begin{array}{c}58 \\
(100.0)\end{array}$ & $\begin{array}{c}133 \\
(100.0)\end{array}$ & $\begin{array}{c}257 \\
(100.0)\end{array}$ \\
\hline
\end{tabular}

Source: Srivastava, A., The Urban Poor in Slums of Jaipur City, Ph.D. Thesis, Department of Anthropology, University of Rajasthan, Jaipur, 2008

\subsection{Emerging issues due to slum level leadership}

Both negative and positive issues emerged because of slum level leadership, which are shared as under:

Support system: In form of slum level leaders, the slum dwellers get a person to whom they can rely, share their problem and can seek help at the time of need. He/She is the one who is accessible to them and hear their problem. Slum dwellers are mainly rural migrant who come to city with lot of hopes. With the support of slum level leaders they try to establish themselves in a completely new environment.

Factionalism: Presence of more than one leader in slum is a boon as well as bane for the slum dwellers. If slum leaders have taken advantage of the weaknesses of slum dwellers to become leader, slum dwellers too have adopted this strategy to choose their own leader, which belong to their community, caste, religion or region. Due to multiple leaders the slums are divided into factions, which weaken the strength of the slum people in raising their demands strongly. Multiple leaders in slum led to formation of groups in a slum on the basis of caste, region and religion.

Harm to community based organization system: Multiple leaders in slums was cited as one of the key reasons to lack faith in the formation of Community Based Organisations (CBOs) because people had perception that CBOs don't have representation of all communities and those who get representation favour only people of their community. About $70 \%$ of respondents favour the formation of community based organization, but those (21\%) who were against its formation perceived that community based organizations are not effective in slum because people are illiterate, labour class, lack devotion, and are divided into groups. Remaining 9\% were unable to give their verdict because they doubt over the credibility of such organisations due to the presence of large number of communities and leaders in slum.

Unethical activities in slums: Slums, an outgrowth of urbanization, are often seen as safe place for criminals to hide. The unethical practices in slum are often the result of umbrella provided by influential personalities to slum dwellers. Slums are the vote bank for any leader to win the election and this is the reason that wrong practices like tapping of electricity, theft of water, encroachment over government land, etc. are overlooked and defended by the slum level leaders in their own fashion. Slum leaders promote encroachment because as the area and population of slum grows it becomes that much difficult for the administration to displace it without proper rehabilitation. Therefore, in this process the slum inhabitants also supported the slum level leaders because they have also similar type of interests.

\section{Conclusion}

Today, we can think of slum free cities, but it is doubtful to have "leader free slums" because representing a small group bring both name and money which raise the social status as well. If slum leaders are properly recognised and counselled by the system then they can be a good resource in managing slum level issues. They can help in environment building by preventing the unethical practices in slums and can improve 
interpersonal relations of slum dwellers. The slum leaders can promote community level ownership and can ensure sustainability of the services once provided at slum level. Also, they can encourage community participation in infrastructure development at slum level, which is envisaged easily in most of the urban development programmes but achieving in reality is a challenge for implementers. Absence of single leadership in slums could be one of the major problems in uniting slum dwellers on development issues. In all the study slums the people were well acquainted with their problems but not well equipped with education and motivation to address those problems. So, if the political parties can mobilise slum level leaders for their political gains, then why not the urban local administration can involve slum level leaders in mobilising the community support in slum improvement?

This strength should be realised properly because development of slums is an urban planning issue but it has political implications as well. Both, slum level leaders and the community should realise each other's strength and work in harmony. For example, in regularised slums the people can form pressure groups under these leaders to mobilise the local administration for slum development. They together can compel the system to make planning more sensitive to local needs.

This whole process is of just 'give' and 'take' but poor people not able to realize their exploitation because they are busy in everyday earning and facing challenges given by urban poverty. On the other hand the slum leaders use them for their own benefits. Consequently, in order to achieve short term petty gains, the long term harms are never perceived by both. Slum dwellers are seen as curse on urban development, but how they are the cause of other's development should be understood deeply through empirical data so that in urban policies we can do justice with them.

\section{References}

[1] Charles Abrams, Housing in the modern world, (Massachusetts Institute of Technology and the President and Fellows of Harvard College; Faber and Faber, 24 Russell Square, London, 1964) , 4

[2] Charles Abrams, Housing in the modern world, (Massachusetts Institute of Technology and the President and Fellows of Harvard College; Faber and Faber, 24 Russell Square, London, 1964), 9

[3] A.R. Desai \& S. Devadas Pillai, General Introduction in A.R Desai \& S. Devadas Pillai, (Ed.) Slums and urbanization, (Bombay Popular Popular Prakashan, 1990), 3

[4] Katharine Coit, Politics and housing strategies in the Anglophone Caribbean, in Brian C. Aldrich \& Ranvinder S. Sandhu (Ed.) Housing the urban poor, Policy and Practice in Developing Countries, (Vistaar Publications, New Delhi, 1995) 173

[5] Shiv Bihari Mathur, Political attitudes of slum dwellers (Aalekh Publishers, Jaipur, 1996), 64

[6] City Mayor Statistics, 2010, available at http://www.citymayors.com/statistics/urban_growth1.html, viewed on 04.02.2013

[7] Report of the Committee on Slum Statistics/ Census, Government of India, (Ministry of Housing and Urban Poverty Alleviation, National Buildings Organisation, 2010), 57 \& 22

[8] Jesper Nylund, Slum renaissance, Rethinking Human Habitats, (Master Thesis, 30 ECTS, Uppsala Universitet, 2009$) 37$

[9] Sandeep Pendse, Political process in a metropolitan slum in A. R. Desai \& S. Devadas Pillai (Ed.) Slums and urbanisation, (Bombay Popular Prakashan, Mumbai, 1990), 298 